\title{
Uses of comet assay techniques to evaluate the effect of green synthesis of nanoparticles of Origanum Vulgare plant for the treatment of lymphocyte cells damage in diabetic patients
}

\author{
Iman A. Mohammed Ali \\ Hazim I. Al-Ahmed* \\ College of Science for women / University of Baghdad \\ * Biotechnology Research Center / Al-Nahrain University \\ E-mail: Sunline_s@yahoo.com
}

Sabah N. Mazhir

\begin{abstract}
Background: Silver nanoparticles are characterized with a high production techniques, in this study nanoparticles were manufactured using Origanum vulgare water extract and $\mathrm{AgnO}_{3}$.

Objective: Experimental factors such as morphology and optical properties of nanoparticles were studied through specific assay such as morphology, spectroscopy of UV rays (UV-Visible), FE-SEM, FT-IR, and Atomic Force Analysis (AFM).

Materials and Methods: showed that the spherical nanoparticles were found using TEM, with an average particle size distribution of $44.2 \pm 88.1 \mathrm{~nm}$ with more than one active plant substance used within the Nano silver compound. In addition, the green nanoparticles have a response in treatment of damage in DNA based on the dose and structure of the nanoparticle in the lymphocytes of the patient with diabetic cells.

Results \&conclusion: These nanoparticles can be considered healthy and can be used without harming healthy parts. The DNA rate in lymphocyte cells was calculated for patients with diabetes using the comet technique. The results showed that the rate of destruction of lymphocytes was reduced for diabetic patient.
\end{abstract}

Keywords: Green synthesis, O. vulgare, Comet Assay.

\section{Introduction}

Nanoparticles are one of the latest trends used in nanotechnology research and include modern active metals (silver, gold, palladium and platinum) used for their optical, photovoltaic and chemical properties. (1) Nanomaterial's can be classified based on the number of dimensions within nanometers $(0 \mathrm{D}, 1 \mathrm{D}, 2 \mathrm{D}$ and 3D) and based on aggregation and drainage (2). . There must be at least one dimension inside the nanometer, i.e. interested 1 and $100 \mathrm{~nm}$ (3).The synthesis of AgNPs is among the most interesting scientific fields at present, using the green chemistry method. The most important characteristic of the main method of green synthesis is that organic solvents and other substances are not used but the use of plant extracts because phytochemicals are directly involved in the reduction of ions and the formation of nanoparticles. From this conclusion, it was found that phenols are the most common agents of reducing agents. Phenol derivatives are usually determined by infrared spectroscopy. Thus, antioxidants, anticancer activities, microbes and silver nanoparticles are greatly increased. Effectiveness of AgNPs was also observed for plant extracts that were identified by many researchers. Nanoparticles were found to have a broad-spectrum antibacterial activity. Including multidrug-resistant human pathogens. In addition, AgNPs have also shown a significant effect against fungal and yeast pathogens. Recently, a significant impact on anticancer activity has been observed from nanoparticles. Where it is emerging today as one of the main areas of confidence in nanotechnology (4). Experiments have begun with cell death by limiting cell proliferation. These experiments were carried out by nutritionists, by promoting intracellular reactive oxygen, DNA damage and cell death. On the other hand, it was found that AgNPs showed a much better anti-cancer activity compared to cisplatin standard medication for cancer (5).

\section{Materials and Method}

\section{Preparation of the Nano extract from the $O$. vulgare solution (NPs)}

The sprocket is converted to a gram weight using the following link:

- $\quad 1 \mathrm{M}$ the equivalent of $169.8 \mathrm{gm}$.

- $1 \mathrm{mM}$ equivalent to $0.170 \mathrm{gm}$.

Taken about $0.085 \mathrm{~g}$ of silver nitrate powder and diluted in $50 \mathrm{ml}$ of DIW. Using the blacksmith, add 50 $\mathrm{ml}$ of silver nitrate solution to $5 \mathrm{~mL}$ of $\mathrm{O} . \mathrm{V}$ solution and use the hot dish with a magnetic drive at $60-90^{\circ} \mathrm{C}$. 
The solution O. vulgare was converted to a Nano extract. The conversion of the water solution to the Nano extract can be derived from light color changes to reddish brown Figure (1).

This is the first evidence of the composition of nanoparticles from AgNo3. This process was performed after we diluted the plant extract several times and using the centrifuge $(6,7)$.

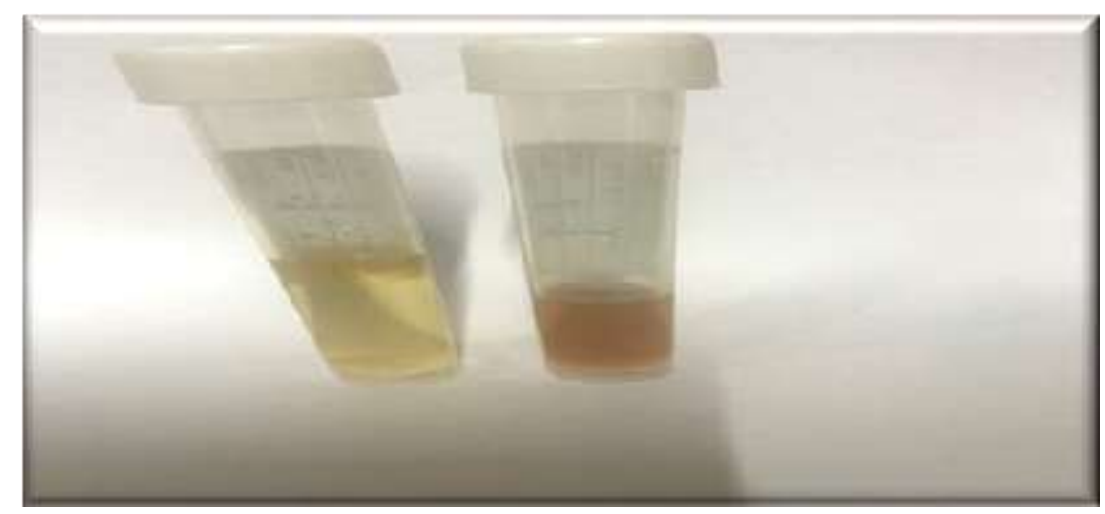

Figure (1): The prenatal compound and after conversion to the NPs

\section{The Measurement techniques}

In order to understand the optical properties, the morphology and structure of the assembled nanoparticles, the size and classification of the nanoparticles were determined according to their dimensions. The various measurements were used and summarized as follows: UV-visible spectra analysis, FT-IR analysis, Scanning electron microscope (SEM), Atomic force microscopy (AFM) analysis, Measurements for electron microscopy (TEM) (7).

\section{Isolation of Lymphocyte from Patient with D.M.}

Lymphocytes were isolated from the patient with D.M. According to the method used in the Biotechnology Research Center / Nahrain University, and were implanted as follows:

1. Take $5 \mathrm{ml}$ of blood into the EDTA tube

2. Add $3 \mathrm{ml}$ of diluted phosphate saline solution (PBS), a balanced local solution used to keep cells away from natural and short-term growth environments.

3. Take $5 \mathrm{ml}$ of the mixture (PBS + Blood) and add to another $5 \mathrm{~mL}$ container of Ficoll solution, a water-like greasy liquid containing a substance used in the biological laboratory to separate the blood into its components (white blood cells, red blood cells).

4. The sample was placed in a centrifuge for 30-45 minutes. The sample appears in layers, spread from top to bottom as follows: plasma and other components, a layer of monochrome nuclei called transparent casing, red blood cells and granular cells.

5. The lymphocytes from Patient with D.M. were collected several times after washing to obtain pure cells.

6. Live cells were withdrawn and placed in flask with the addition of RPMI-1640 containing L-Glutamine, a medium used to support the growth of living cells, as well as $9 \%$. In addition, supplemented with fetal bovine serum at $1 \%$.

7. It was kept in the incubator at $37{ }^{\circ} \mathrm{C}$. and left in $5 \% \mathrm{CO}_{2}$ and $95 \%$ relative humidity for 24 hours. Until cells grow.

Testing of toxic nanoparticle extracts on living cell lines

After we isolated lymphocyte from Patient with D.M. Cell Line, they were examined under a microscope to ensure their normal growth. The cells were exposed after distribution in the 96-hole multi-hole plate and were treated using prepared extracts and cold plasma using micropipette absorbent (6).

Direct exposure to NPs

Lymphocytes cells were directly exposed to NPs with six different concentrations $(80,40,20,10$, and 5) $\mathrm{nm}$.And three replicates per concentration. The best inhibitory of DNA damage was found at $80 \mathrm{~nm}$ concentrations, so this concentration was adopted. 


\section{Comet Assay}

In this study, we used comet Assay techniques to detect damaged DNA in the lymphocyte cells in diabetic patient Figure (2). This technique is used to detect various diseases caused by environmental pollution, genetic diseases or any physical or chemical source that causes damage to DNA (8).
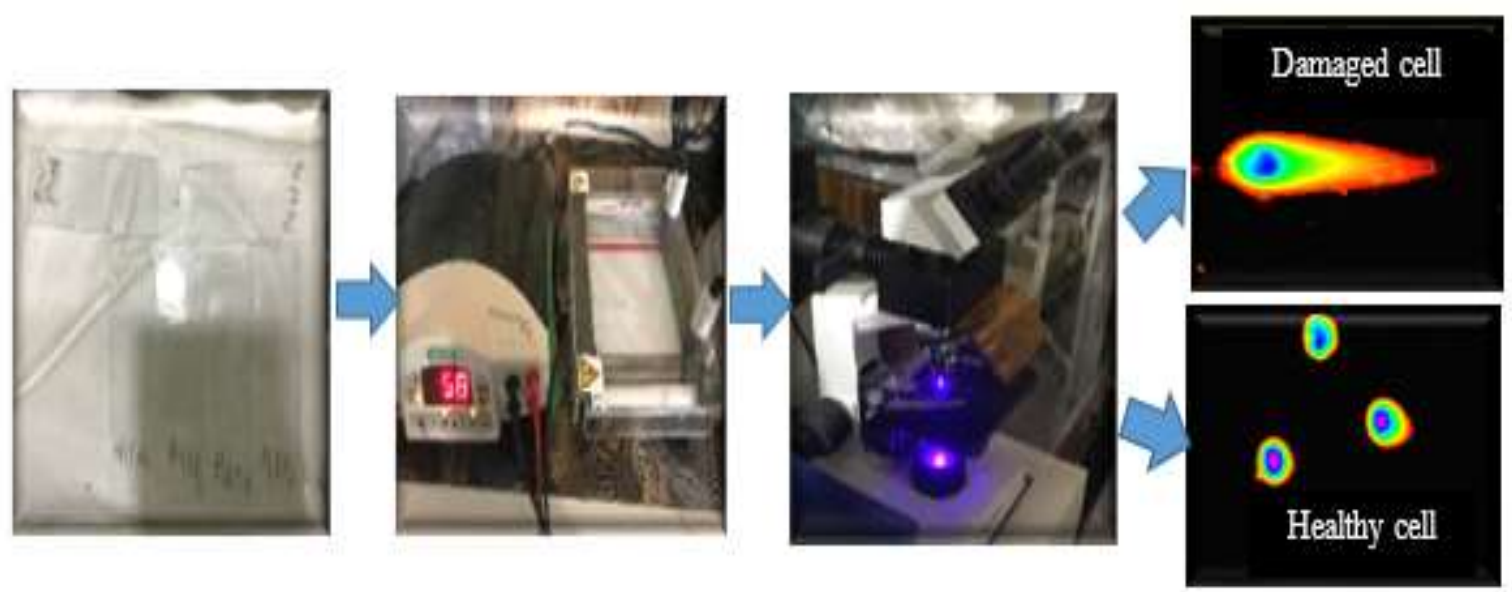

Figure (2): Comet assay test

\section{Statistical analysis}

The results were subjected to statistical analysis in order to identify the differences between the different results for each of the nanoparticles and direct exposure to plasma. Using the Windows SPSS Veirsion18 statistical program, the sample methods were evaluated using the (ANOVA) test and the mean (Mean \pm SD) was found. $\mathrm{P} \leq 0.05$ values were considered significant.

\section{Result and Discussion}

Alkaline Comet Assay

The result in Table (1) and Figure (3) Indicates, that the large and medium damage of DNA was significantly reduced $(\mathrm{P} \leq 0.05)$ for damage by lymphocytes in diabetic patient. In addition, when exposed to direct NPs in $(35.833 \pm 6.113)$ and $(33.333 \pm 5.785)$, compared with negative control, while other concentrations showed a significant decrease $(\mathrm{P} \leq 0.05)$ for damage but less effect. Nanoparticles in O. vulgare act to protect DNA by increasing oxidative activity in the immune system, thereby preventing ROS from stimulating lipid peroxidation responsible for subsequent DNA damage. This result matches the previous study in the source (9).

Table (1): showes the result of comet assay of lymphocyte cell from patient with D.M after treated by NPs at concentration $(80) \mathrm{nm}$

\begin{tabular}{c|c|c|c|c}
\hline Parameters & $\begin{array}{c}\text { No Damage } \\
\%(\text { mean } \pm \text { SD })\end{array}$ & $\begin{array}{c}\text { Low Damage } \\
\%(\text { mean } \pm \text { SD })\end{array}$ & $\begin{array}{c}\text { Medium } \\
\text { Damage } \\
\%(\text { mean } \pm S D)\end{array}$ & $\begin{array}{c}\text { High Damage } \\
\%(\text { mean } \pm \text { SD })\end{array}$ \\
\hline Control & $\mathbf{1 2 . 3 7 7 \pm 1 . 6 5 8}$ & $19.167 \pm 3.488$ & $61.000 \pm 6.481$ & $67.500 \pm 9.354$ \\
NPs & $24.818 \pm 2.558$ & $43.500 \pm 11.828$ & $35.833 \pm 6.113$ & $33.333 \pm 5.785$ \\
LSD & 2.067 & 9.225 & 5.729 & 7.597 \\
P-value & 0.00053 & 0.00034 & 0.00012 & 0.005 \\
\hline
\end{tabular}





Figure (3): Comet assay for the Lymphocyte from Patient with D.M. Cell after the treatment

\section{Conclusions}

Our experience has shown that silver nanoparticles of $O$. Vulgare plant. Very effective in activating lymphocytes for diabetic patients. At the same time, DNA damage in the diabetic patient ceases. These nanoparticles can be considered healthy and can be used without harming healthy parts.

\section{References}

1. Kumar B, Smita K, Seqqat R, Benalcazar K, Grijalva M, Cumbal L. In vitro evaluation of silver nanoparticles cytotoxicity on Hepatic cancer (Hep-G2) cell line and their antioxidant activity: Green approach for fabrication and application. J. of Photochemistry \& Photobiology, B: Biology. (2016); 159:8-13.

2. Darweesh HHM. Nanomaterials: Classification and Properties-Part I. CITS. (2018); 1:1-11.

3. Zhang B. Physical fundamentals of nanomaterials: William Andrew; (2018).

4. Abbasi E, Milani M, Fekri Aval S, Kouhi M, Akbarzadeh A, Tayefi Nasrabadi H, et al.. Silver nanoparticles: synthesis methods, bio-applications and properties. Critical reviews in microbiology. (2016); 42(2):173-80.

5. Usmani A, Dash PP, Mishra A. Metallic Nano formulations: Green synthetic approach for advanced drug delivery. Materials Science. (2018); 2(2):1-4.

6. Yaaqoob L. Effect of Using Zinc Oxide and Gold Nanoparticles on Experimentally Induced Diabetic Rats. A thesis .PhD (dissertation) .Submitted to the College of Sciences. University of Baghdad. ( 2016).

7. Sankar R, Karthik A, Prabu A, Karthik S, Shivashangari KS, Ravikumar VJC, et al.. Origanum vulgare mediated biosynthesis of silver nanoparticles for its antibacterial and anticancer activity. Science Direct. (2013); 108:80-84.

8. Peter KV, editor. Handbook of herbs and spices. Elsevier.(2012) 21.

9. Arami S, Ahmadi A, Haeri SA. The radio protective effects of Origanum vulgare extract against genotoxicity induced by $131 \mathrm{I}$ in human blood lymphocyte. Cancer Biotherapy and Radiopharmaceuticals. (2013) 1; 28(3):201-6. 